Article

\title{
Repeated Fish Removal to Restore Lakes: Case Study of Lake Væng, Denmark-Two Biomanipulations during 30 Years of Monitoring
}

\author{
Martin Søndergaard ${ }^{1,2, *}$, Torben L. Lauridsen ${ }^{1,2}$, Liselotte S. Johansson ${ }^{1}$ and Erik Jeppesen ${ }^{1,2}$ \\ 1 Department of Bioscience, Aarhus University, Vejlsøvej 25, 8600 Silkeborg, Denmark; tll@bios.au.dk (T.L.L.); \\ lsj@bios.au.dk (L.S.J.); ej@bios.au.dk (E.J.) \\ 2 Sino-Danish Centre for Education and Research, 8000 Aarhus, Denmark \\ * Correspondence: ms@bios.au.dk; Tel.: +45-871-5995
}

Academic Editor: Benoit Demars

Received: 19 August 2016; Accepted: 4 January 2017; Published: 11 January 2017

\begin{abstract}
Biomanipulation by fish removal has been used in many shallow lakes as a method to improve lake water quality. Here, we present and analyse 30 years of chemical and biological data from the shallow and 16 ha large Lake Væng, Denmark, which has been biomanipulated twice with a 20-year interval by removing roach (Rutilus rutilus) and bream (Abramis brama). After both biomanipulations, Lake Væng shifted from a turbid, phytoplankton-dominated state to a clear, water macrophyte-dominated state. Chlorophyll $a$ was reduced from $60-80 \mu \mathrm{g} \cdot \mathrm{L}^{-1}$ to $10-30 \mu \mathrm{g} \cdot \mathrm{L}^{-1}$ and the coverage of submerged macrophytes, dominated by Elodea canadensis, increased from $<0.1 \%$ to $70 \%-80 \%$. Mean summer total phosphorus was reduced from about 0.12 to $0.07 \mathrm{mg} \cdot \mathrm{L}^{-1}$ and total nitrogen decreased from 1.0 to $0.4 \mathrm{mg} \cdot \mathrm{L}^{-1}$. On a seasonal scale, phosphorus and chlorophyll concentrations changed from a summer maximum during turbid conditions to a winter maximum under clear conditions. The future of Lake Væng is uncertain and a relatively high phosphorus loading via the groundwater, and the accumulation of a mobile P pool in the sediment make it likely that the lake eventually will return to turbid conditions. Repeated fish removals might be a relevant management strategy to apply in shallow lakes with a relatively high external nutrient loading.
\end{abstract}

Keywords: biomanipulation; clear water; turbid water; chlorophyll $a$; nutrients; Elodea

\section{Introduction}

Biomanipulation by removing zooplanktivorous and benthivorous fish has been used as a method to restore and improve lake water quality for many years [1-5]. By decreasing the top-down control from fish on particularly large-sized zooplankton, the aim is to increase the filtration of zooplankton capacity on phytoplankton and thereby create clearer water. Removal of benthivorous fish species such as carp (Cyprinus carpio), gizzard shad (Dorosoma cepedianum) and bream (Abramis brama) may also improve lake water quality in shallow lakes by reducing the sediment resuspension and nutrient recycling caused by their feeding activity [6,7] and possibly also by reducing the amount of loose sediment, which otherwise would be more easily resuspended by wind [8].

Numerous examples of biomanipulation have been given in the literature during the past 30 years, including more general approaches integrating the results from a number of case studies [6,9-11]. Overall, clear effects of biomanipulation have often been recorded, among these a trophic cascade impacting most trophic levels; however, the effects have sometimes been weak [12-14]. In some biomanipulation projects, for example those undertaken in Danish lakes, a clear tendency to a return to the previous turbid conditions after 5 to 10 years has been observed [10]. The failure to establish a long-lasting clear water state and inability to create permanent effects have been ascribed to a number 
of factors. First, adequate reduction of the external nutrient loading is crucial to obtain permanent effects $[2,3,15,16]$. In shallow lakes, TP concentrations below $0.05 \mathrm{mg} \cdot \mathrm{L}^{-1}$ have been suggested as a prerequisite of this [17]. Furthermore, a sufficient number of fish need to be removed, depending also on TP concentrations [18]. In shallow lakes, extensive cover of submerged macrophytes is important for stabilising and maintaining clear water conditions [19], and the overall biomanipulation success may depend on the internal nutrient loading and the interacting effects of nutrient concentrations, fish recolonization and macrophyte abundance $[11,14,20]$.

Post-restoration data sets rarely cover more than a few years after restoration, which renders it difficult to draw any firm conclusions on how often long-term or permanent effects are achieved. Most lake restorations are conducted as a single intervention and repeated lake restorations via fish removal are rare. If a first biomanipulation is not successful in the long term, it has been suggested that a second biomanipulation demands less effort due to the slow recovery of some large benthivores, higher abundance of potential piscivores (e.g., perch, Perca fluviatilis) and reduced risk of high internal phosphorus loading [6].

In this paper, we describe the results obtained from two biomanipulation cases conducted with a 20-year interval in Lake Væng, Denmark. The lake has been monitored yearly since 1986 for a number of chemical and biological parameters. Our aim was to study the long-term effects of fish biomanipulation on different trophic levels and nutrient dynamics and to investigate the impacts of repeated fish removal as a lake restoration tool. Our hypothesis was that repeated fish removal would imitate the effects achieved by the first biomanipulation, but with less fishing effort.

\section{Materials and Methods}

\subsection{Study Area}

Lake Væng is a small and shallow lake situated in the central part of Jutland, Denmark (Figure 1, Table 1). The catchment is $9 \mathrm{~km}^{2}$ and consists mainly of extensive agricultural areas and forests. The lake has a short hydraulic retention time (15-25 days) and hydraulic loading is dominated by groundwater, which comprises about $70 \%$ of the total hydraulic input. The lake sediment is soft and rich in organic matter.

From 1964, the lake received wastewater from a small village, but this was diverted in 1981, projected to reduce the external phosphorus loading from 4 to $1.5 \mathrm{~g} \cdot \mathrm{P} \cdot \mathrm{m}^{-2} \cdot \mathrm{year}^{-1}$ [2]. However, the lake remained eutrophic with a mean summer Secchi depth of 0.6-0.8 m (1981-1986), chlorophyll $a$ concentrations of $76 \mu \mathrm{g} \cdot \mathrm{L}^{-1}$ (1986) and dominance of cyanobacteria [20]. No known changes have occurred in the external nutrient loading since 1981. Lake Væng and topics related to its restoration have previously been described in various papers [6,21-24].

Table 1. Morphological and chemical characteristics of Lake Væng (mean values for the monitoring period).

\begin{tabular}{lc}
\hline \multicolumn{1}{c}{ Parameter } & Value \\
\hline Area (ha) & 16 \\
Mean depth (m) & 1.2 \\
Maximum depth (m) & 1.9 \\
Hydraulic retention time (days) & $15-25$ \\
Hydraulic loading via groundwater (\% of total water inlet) & 70 \\
Alkalinity (meq. $\mathrm{L}^{-1}$ ) & $0.7-1.5$ \\
\hline
\end{tabular}




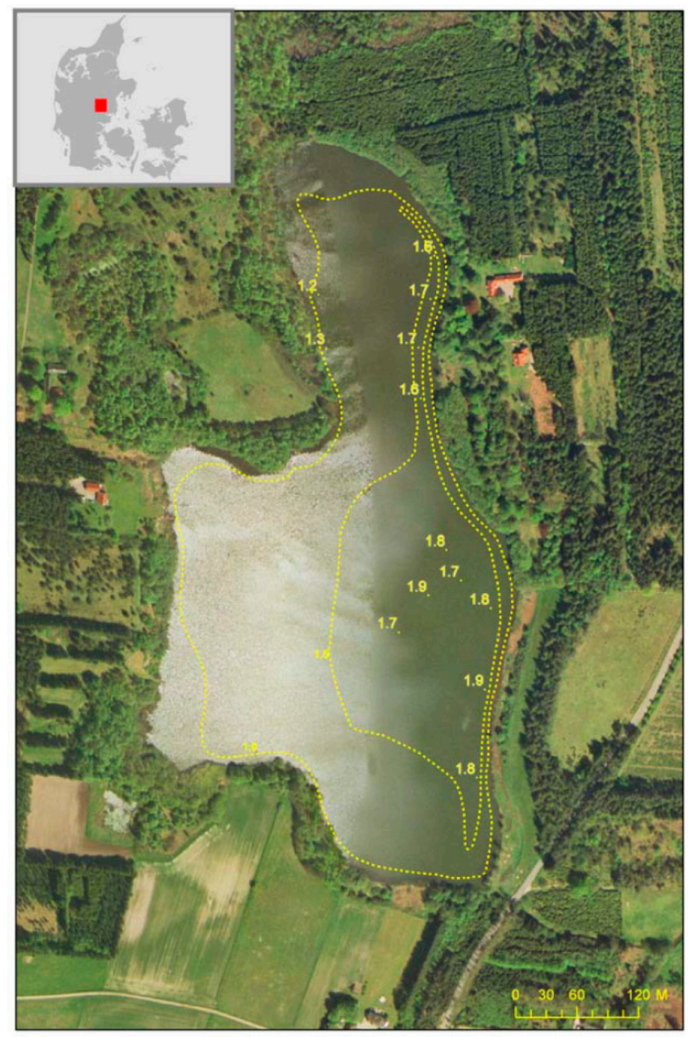

Figure 1. Bathymetry of Lake Væng with 1.0 and $1.5 \mathrm{~m}$ depth contours. Geographical location is shown in the upper left corner $\left(56^{\circ} 02^{\prime} \mathrm{N}, 9^{\circ} 39^{\prime} \mathrm{E}\right)$.

\subsection{Biomanipulation}

Biomanipulation involving removal of zooplanktivorous and benthivorous fish species was conducted in Lake Væng using gill nets, fish traps, fish trawling and electrofishing. The first biomanipulation took place from autumn 1986 until summer 1988 and a total of 4 tons fish, corresponding to 201,000 individuals, were removed from the lake (Table 2). Of the fish removed, the zooplanktivorous roach (Rutilus rutilus) comprised $98 \%$ by number and $38 \%$ by weight, while bream comprised $1 \%$ by number and $62 \%$ by weight. Piscivorous pike (Esox lucius) and large perch caught during the fishing were released into the lake again. The removal was estimated to have reduced the total biomass of zooplanktivorous and benthivorous fish by approximately $50 \%-70 \%$ [21].

In the second biomanipulation from October 2007 to May 2009, less (2.8 tons) fish were removed and, again, roach and bream comprised the majority of the fish biomass removed, constituting, respectively, $32 \%$ and $55 \%$ (Table 2 ).

Table 2. Fish biomass (kg wet weight) removed during the first and the second biomanipulation in Lake Væng. "Others/mixed" comprise a few other species (ruffe (Gymnocephalus cernua) and ide (Leuciscus idus)) and unidentified fish species. No data are available on fish numbers in the second biomanipulation.

\begin{tabular}{lccc}
\hline \multirow{2}{*}{ Species } & \multicolumn{2}{c}{$\mathbf{1 9 8 6 - 1 9 8 8}$} & $\mathbf{2 0 0 7 - 2 0 0 9}$ \\
\cline { 2 - 4 } & Number (\% of Total) & Biomass (\% of Total) & Biomass (\% of Total) \\
\hline Bream (Abramis brama) & $2528(1)$ & $2457(62)$ & $1508(55)$ \\
Perch (Perca fluviatilis) & 0 & 0 & $65(2)$ \\
Pike (Esox lucius) & 0 & 0 & $24(1)$ \\
Roach (Rutilus rutilus) & $196,851(98)$ & $1505(38)$ & $882(32)$ \\
Rudd (Scardinius erythrophthalmus) & $708(<1)$ & $22(<1)$ & $28(1)$ \\
Tench (Tinca tinca) & 0 & 0 & $31(1)$ \\
Others/mixed & $846(<1)$ & $7(<1)$ & $212(8)$ \\
\hline Total & 200,933 & 3991 & 2750 \\
\hline
\end{tabular}




\subsection{Sampling}

Water samples for chemical analyses were taken with a tube sampler (diameter $7.5 \mathrm{~cm}$ ) from the central part of the lake as an integrated sample from the surface to $10 \mathrm{~cm}$ above the sediment. From 1986 to 2015, sampling was conducted 1 to 4 times a month during summer (May-September) and in most years at least once a month during the rest of the year.

Submerged macrophytes were sampled every month during summer and usually at least once during winter (December-February) when macrophytes were present. Water depth, species composition, cover of individual species, total cover and plant height were recorded at 41-192 sampling positions (average $=89$ positions, most at dense macrophyte cover), representing the whole lake area. Mean macrophyte cover (Cov, as percentage of the whole lake area, excluding filamentous algae) and mean plant volume inhabited (PVI, PVI $=\mathrm{Cov} \times$ plant height/water depth) corresponding to the percentage of the water volume occupied by plants were calculated for each sampling date.

Fish stock composition and relative biomass were investigated with standardised methods every year from 1989 to 2011 and every second year from 2011 to 2015. The fish monitoring was conducted from 15 August to 15 September using eight to twelve $42 \mathrm{~m}$ long multiple mesh-sized gill nets with 14 different mesh sizes ranging from $6.25 \mathrm{~mm}$ to $75 \mathrm{~mm}[25,26]$. The nets were set in different parts of the lake in late afternoon and retrieved after 18 hours. Except for unharmed large pike, fish caught during the monitoring were not released into the lake again. Quantitative measurements of the total fish stock and the individual species were expressed as catch per unit effort of weight (WPUE) or numbers (NPUE). It should be noted that bream is not easily caught in these survey nets and its relative abundance may have been underestimated.

\subsection{Secchi Depth and Chemical Analyses}

Secchi depth and chemical analyses included chlorophyll $a$ (CHL), total phosphorus (TP), dissolved inorganic phosphorus (DIP), total nitrogen (TN) and dissolved inorganic nitrogen (DIN) calculated as the sum of the concentration of ammonium, nitrate and nitrite. All chemical analyses were performed using standard analytical procedures (see [27] for further details). Except for seasonal data or if otherwise mentioned, all chemical data presented are mean summer concentrations calculated as averages from 1 May to 30 September. In years with clear water, Secchi depth often reached the bottom of the lake and in these cases this was recorded as the Secchi depth.

\subsection{Data Analyses}

A summer winter ratio obtained by dividing mean summer concentrations (1 May-30 September) by mean concentrations the following winter (1 December-27 February) was calculated for TP (TPs_w), TN (TNs_w), DIP (DIPs_w) and CHL (CHLs_w). As DIN was close to or below the detection limit in most summers, a summer-winter ratio was not calculated for DIN. Statistical tests (t-test) were performed using SAS Proc $t$-test with Bonferroni correction to identify differences between the first and second biomanipulation and differences between years with high and low Cov.

Low $\operatorname{Cov}(\operatorname{Cov}<10 \%)$ and high $\operatorname{Cov}(\operatorname{Cov}>20 \%)$ were used to define turbid and clear water periods, respectively. A Cov threshold of ca. $20 \%$ has been shown to markedly influence phytoplankton biomass and the CHL:TP ratio in shallow Danish lakes [28].

\section{Results}

\subsection{Fish}

In the first years after the first biomanipulation, WPUE was $<1.5 \mathrm{~kg} \cdot$ net $^{-1}$ and NPUE was $<100$ net $^{-1}$ (Figure 2). From 1991, WPUE increased rapidly to $3-6 \mathrm{~kg} \cdot \mathrm{net}^{-1}$ and NPUE rose gradually during the next 10 years to $300-600$ net $^{-1}$. After the second biomanipulation, WPUE declined to $2-4 \mathrm{~kg} \cdot$ net $^{-1}$ and NPUE to about 50 net $^{-1}$. During the whole period, roach and perch completely dominated the fish stock, and in most years they constituted more than $80 \%$ in both number and weight. 
The relative importance of perch was highest in the first years after biomanipulation, particularly after the first intervention. For a few years after the first biomanipulation, pike constituted about $20 \%$ of WPUE, and in some years bream constituted 10\%-20\% of both WPUE and NPUE.

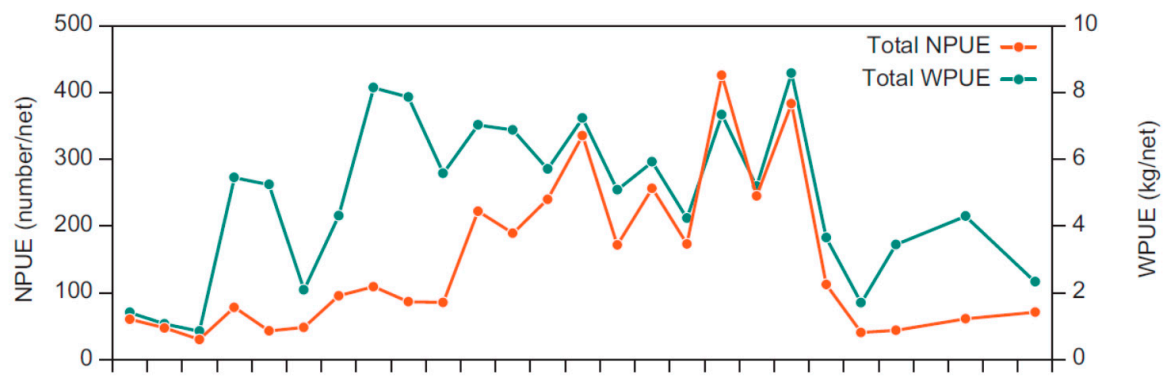

(a)

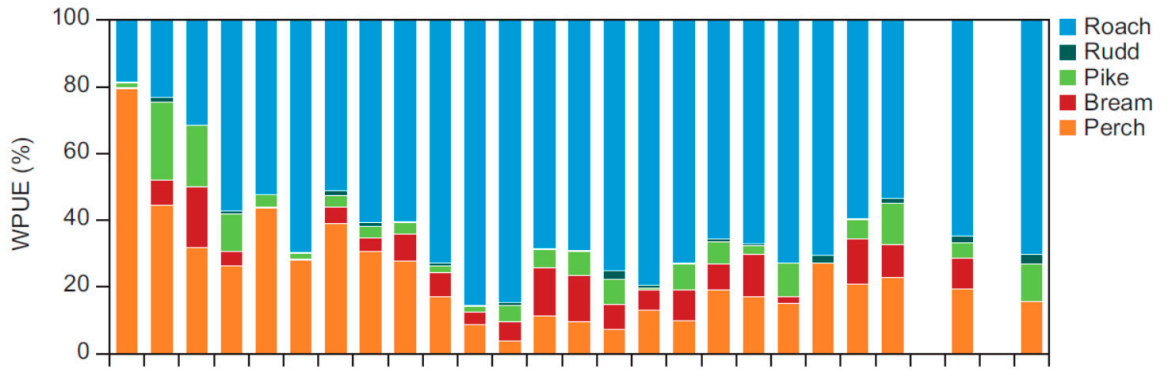

(b)

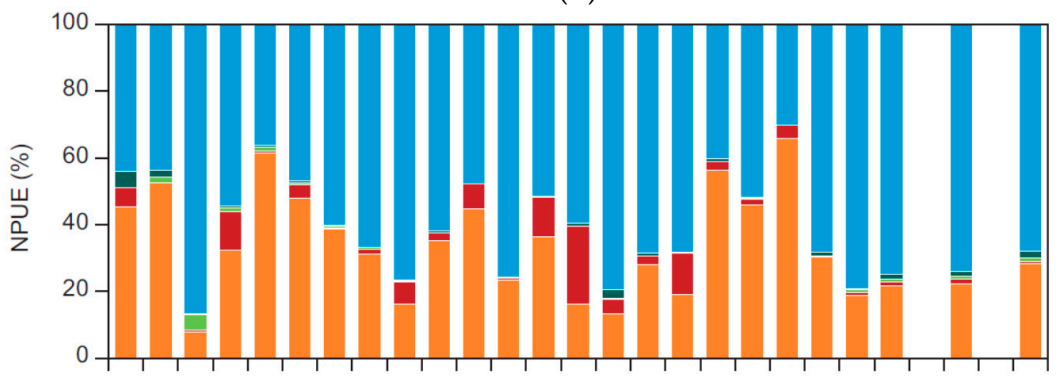

(c)

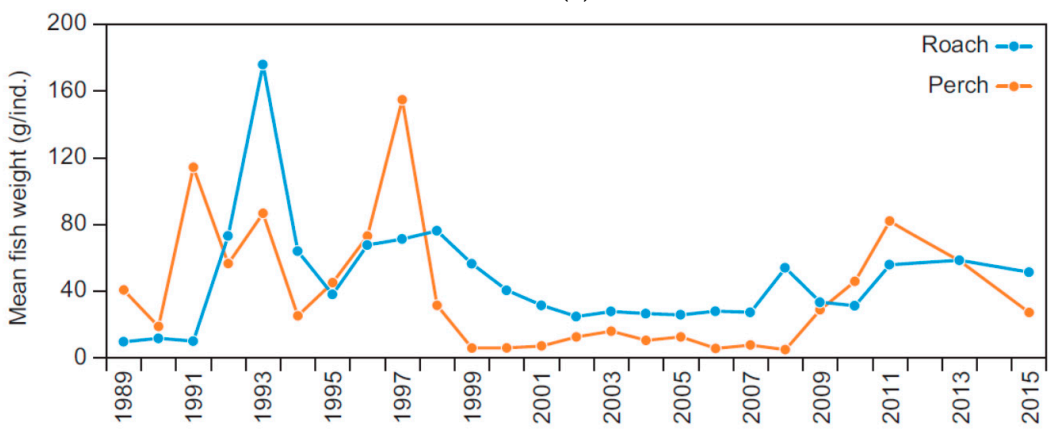

(d)

Figure 2. (a) Changes in relative fish biomass: WPUE (catch per unit effort of weight) and NPUE (catch per unit effort of weight of number); (b) relative fish biomass; (c) number composition; (d) mean weight of roach and perch during the monitoring period. The second biomanipulation was conducted from 2007 to 2009.

The individual weight of both perch and roach was highest in the first years after the two biomanipulations, albeit with large year-to-year fluctuations, particularly in the clear water periods (Figure 2). In the turbid period between the two biomanipulations (1999-2008), especially perch had a low individual weight, varying between 5.1 and $16.2 \mathrm{~g} \cdot \mathrm{ind}^{-1}$, while its weight in the first clear water 
period (1989-1998) varied from 18.9 to $154.9 \mathrm{~g} \cdot \mathrm{ind}^{-1}$ and in the second clear water period (2009-2015) from 27.3 to $82.2 \mathrm{~g}$. ind $^{-1}$. For the whole monitoring period, the mean weights of perch and roach did not differ significantly between periods with high and low Cov (Table 3).

Table 3. Mean (summer and/or winter with min-max shown in parentheses) Secchi depth, CHL, nutrient concentrations, Cov and fish data in years with low $\operatorname{Cov}(\operatorname{Cov}<10 \%$ : 1986-1988, 1993, 1997-2008, $n=16$ ) and years with high $\operatorname{Cov}(\operatorname{Cov}>20 \%$ : 1989-1991, 1994-1995, 2009-2015, $n=12$ ). No summer mean concentrations of $\mathrm{NO}_{3}$ and $\mathrm{NH}_{4}$ are given since these were often below the detection limit. The five last rows show summer-winter ratios of CHL (CHLs_w) and nutrients (TPs_w, DIPs_w, TNs_w and DINs_w). $t$-Test results for difference between low and high Cov ae given in the right column (significant differences are marked with bold). According to the Bonferroni correction for multiple comparisons, the results were considered significant for $p<0.0025$, representing an overall alpha level of $<0.05$.

\begin{tabular}{|c|c|c|c|}
\hline Variable & Low Cov & High Cov & Difference Low-High Cov \\
\hline Secchi, summer (m) & $0.87(0.61-1.46)$ & $1.51(1.24-1.78)$ & $p<0.001$ \\
\hline Cov, summer (\%) & $0.8(0-4)$ & $67.6(22-86)$ & $p<0.001$ \\
\hline $\mathrm{CHL}$, summer $\left(\mu \mathrm{g} \cdot \mathrm{L}^{-1}\right)$ & $62.1(21.3-85.0)$ & $16.9(9.4-29.5)$ & $p<0.001$ \\
\hline $\mathrm{CHL}$, winter $\left(\mu \mathrm{g} \cdot \mathrm{L}^{-1}\right)$ & $21.3(11.6-40.3)$ & $31.2(5.1-253.5)$ & $p=0.58$ \\
\hline $\mathrm{TN}$, summer $\left(\mathrm{mg} \cdot \mathrm{L}^{-1}\right)$ & $0.97(0.60-1.25)$ & $0.40(0.14-0.68)$ & $p<0.001$ \\
\hline $\mathrm{TN}$, winter $\left(\mathrm{mg} \cdot \mathrm{L}^{-1}\right)$ & $0.97(0.65-1.40)$ & $1.01(0.40-2.00)$ & $p=0.69$ \\
\hline $\mathrm{NO}_{3}$, winter & $0.555(0.407-0.655)$ & $0.492(0.185-0.715)$ & $p=0.13$ \\
\hline $\mathrm{NH}_{4}$, winter & $0.083(0-0.268)$ & $0.102(0-0.261)$ & $p=0.52$ \\
\hline $\mathrm{TP}$, summer $\left(\mathrm{mg} \cdot \mathrm{L}^{-1}\right)$ & $0.120(0.082-0.151)$ & $0.067(0.034-0.169)$ & $p<0.001$ \\
\hline $\mathrm{TP}$, winter $\left(\mathrm{mg} \cdot \mathrm{L}^{-1}\right)$ & $0.060(0.40-0.73)$ & $0.090(0.040-0.283)$ & $p=0.07$ \\
\hline DIP summer & $0.049(0.030-0.084)$ & $0.036(0.014-0.136)$ & $p=0.17$ \\
\hline DIP winter & $0.032(0.020-0.039)$ & $0.063(0.023-0.120)$ & $p=0.001$ \\
\hline WPUE (kg) & $6.3(4.2-8.6)$ & $2.5(0.8-4.3)$ & $p<0.001$ \\
\hline NPUE & $220(43-426)$ & $58(30-112)$ & $p<0.001$ \\
\hline Perch_w (g) & $28.1(5-155)$ & $48.6(19-114)$ & $p=0.22$ \\
\hline Roach_w (g) & $51.4(25-176)$ & $36.6(10-64)$ & $p=0.32$ \\
\hline CHLs_w & $3.47(1.34-6.23)$ & $1.46(0.07-5.06)$ & $p=0.0017$ \\
\hline TPs_w & $2.30(1.43-3.03)$ & $0.75(0.21-1.68)$ & $p<0.001$ \\
\hline DIPs_w & $1.61(0.86-2.46)$ & $0.49(0.21-1.21)$ & $p<0.001$ \\
\hline TNs_w & $1.02(0.69-1.26)$ & $0.36(0.12-0.62)$ & $p<0.001$ \\
\hline
\end{tabular}

\subsection{Secchi Depth, CHL and Nutrient Concentrations}

Summer means of Secchi depth, CHL and nutrient concentrations were highly variable during the 30 years of monitoring (Figure 3). After the first biomanipulation, Secchi depth increased from $0.6 \mathrm{~m}$ to 1.3-1.6 $\mathrm{m}$ from 1988 to 1996 but then declined to $0.6-0.8 \mathrm{~m}$ during the following 10 years. After the second biomanipulation (2010-2015), Secchi depth increased to above $1.5 \mathrm{~m}$ or the maximum depth of the lake. CHL varied correspondingly, with high concentrations $\left(60-80 \mu \mathrm{g} \cdot \mathrm{L}^{-1}\right)$ before the two biomanipulations and low concentrations $\left(10-30 \mu \mathrm{g} \cdot \mathrm{L}^{-1}\right)$ for a period after the two biomanipulations. CHL increased steadily from a minimum in $1991\left(9.4 \mu \mathrm{g} \cdot \mathrm{L}^{-1}\right)$ to a maximum before the second biomanipulation of $85 \mu \mathrm{g} \cdot \mathrm{L}^{-1}$ in 2006. Secchi depth was significantly higher and CHL significantly lower in periods with high Cov than in periods with low Cov (Table 3).

Nitrogen and phosphorus concentrations also varied and were generally lowest in the clear water periods with high Cov following the two biomanipulations (TP: 0.03-0.17 $\mathrm{mg} \cdot \mathrm{L}^{-1}$; TN: $0.1-0.7 \mathrm{mg} \cdot \mathrm{L}^{-1}$ ) and highest under turbid conditions with low Cov before the biomanipulations (TP: $0.08-0.15 \mathrm{mg} \cdot \mathrm{L}^{-1}$, TN: 0.6-1.3) (Table 3). Especially after the second biomanipulation from 2010 and onwards, TP and TN reached low levels (Figure 3). 

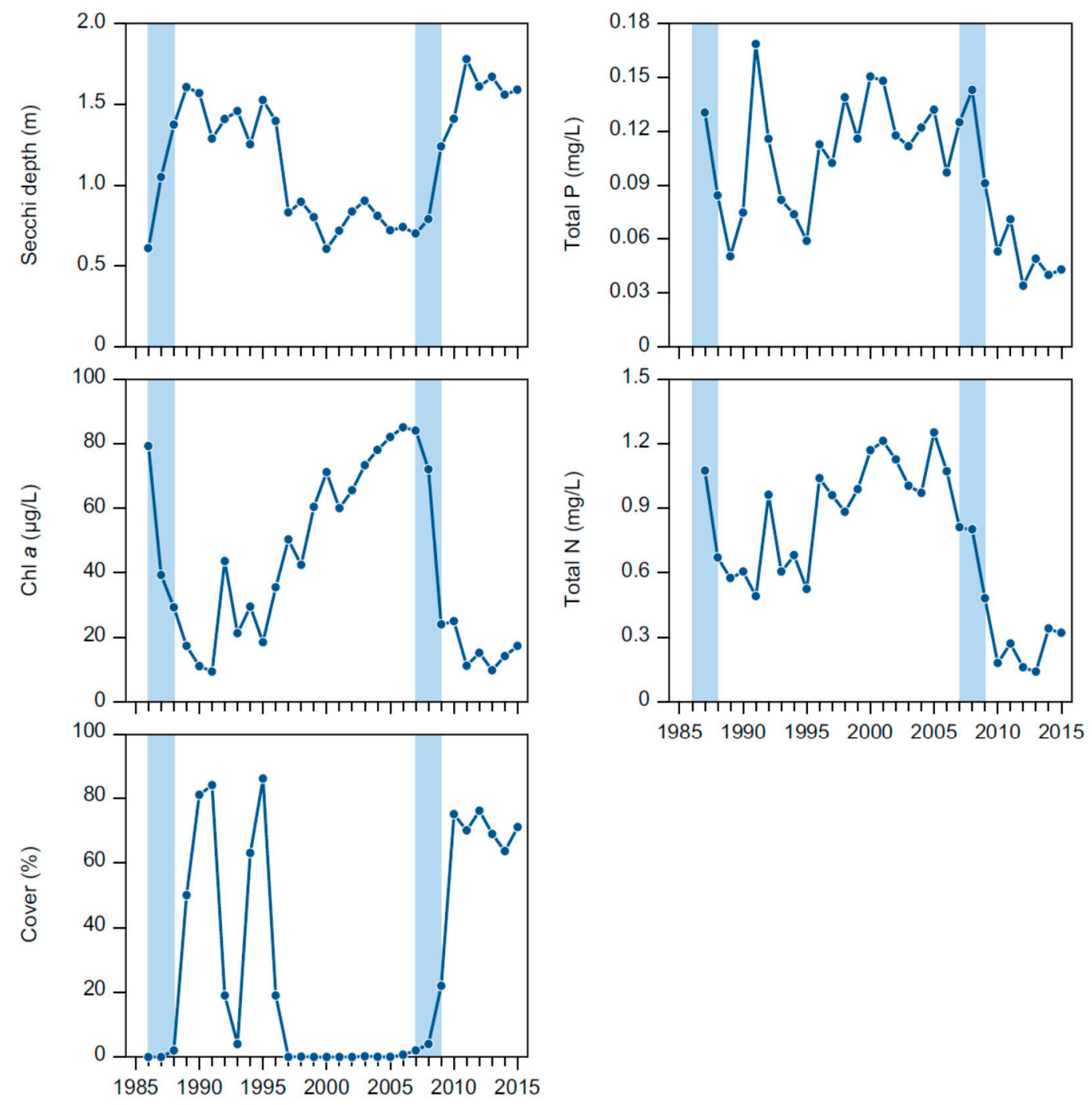

Figure 3. Mean summer Secchi depth, CHL, cover of submerged macrophytes and concentrations of nutrients (TN and TP) from 1986 to 2015. The two periods with fish removal (1986-1988 and 2007-2009) are indicated with blue columns.

On a seasonal scale over the past 10 years, CHL, phosphorus and nitrogen demonstrated marked seasonality, but the seasonal pattern changed after the biomanipulation (Figure 4). Before the second biomanipulation and before the reappearance of high macrophyte Cov (2006-2009), summer CHL and TP concentrations were significantly higher than during the following period when macrophyte Cov was high (2011-2015, Table 4). For example, mean summer TP reached $0.084-0.170 \mathrm{mg} \cdot \mathrm{L}^{-1}$ at low Cov compared with $0.036-0.072 \mathrm{mg} \cdot \mathrm{L}^{-1}$ at high Cov. In years with a summer peak in TP, this was partly due to increased DIP concentrations, but in years with winter TP peaks this was mainly due to increased DIP concentrations. As to TN, winter peaks were mainly caused by increased nitrate concentrations, ammonia being a contributory factor when submerged macrophytes reappeared. Only TP during summer was significantly different between years with high and low Cov. Before the macrophytes returned, CHL concentrations were usually highest during summer (up to $123-137 \mu \mathrm{g} \cdot \mathrm{L}^{-1}$ ), but after the return of macrophytes the concentrations were low in summer (mean summer CHL: $10-25 \mu \mathrm{g} \cdot \mathrm{L}^{-1}$ ) and comparatively high (up to $96 \mu \mathrm{g} \cdot \mathrm{L}^{-1}$ ) in winter or early spring (Figure 4 ). 



Figure 4. Seasonal variations in $\mathrm{CHL}, \mathrm{TP}, \mathrm{DIP}, \mathrm{TN}, \mathrm{NO}_{3}$ and $\mathrm{NH}_{4}$, during the past 10 years. The blue arrow denotes occurrence of high macrophyte cover.

Table 4. Mean CHL and nutrient concentrations during summer months (June, July and August) and winter/spring months (January, February and March) during a period with low Cov (2006-2009) and a period with high Cov (2011-2015) as shown in Figure 4. $t$-Test results for differences between years (summer or winter/spring months) with high and low Cov (significant differences are marked with bold). According to the Bonferroni correction for multiple comparisons, the results were considered significant for $p<0.0045$, representing an overall alpha level of $<0.05$. During summer, $\mathrm{NO}_{3}$ was always below the detection limit $\left(<0.01 \mathrm{mg} \cdot \mathrm{L}^{-1}\right)$ and is not included.

\begin{tabular}{cccc}
\hline Variable & $\begin{array}{c}\text { 2006-2009 (Low Cov) } \\
\text { Mean (Min-Max) }\end{array}$ & $\begin{array}{c}\text { 2011-2015 (High Cov) } \\
\text { Mean (Min-Max) }\end{array}$ & $\begin{array}{c}\text { Difference } \\
\text { (Low-High Cov) }\end{array}$ \\
\hline CHL summer & $70.7(30.0-94.5)$ & $11.5(8.1-16.2)$ & $p=0.028$ \\
CHL winter & $30.0(30.8-45.3)$ & $46.3(18.9-96.1)$ & $p=0.53$ \\
TP summer & $0.128(0.084-0.170)$ & $0.048(0.036-0.072)$ & $p=0.002$ \\
TP winter & $0.059(0.054-0.062)$ & $0.086(0.051-0.128)$ & $p=0.15$ \\
DIP summer & $0.061(0.047-0.098)$ & $0.027(0.016-0.049)$ & $p=0.029$ \\
DIP winter & $0.029(0.018-0.034)$ & $0.057(0.034-0.078)$ & $p=0.047$ \\
TN summer & $0.79(0.47-0.66)$ & $0.27(0.19-1.25)$ & $p=0.045$ \\
TN winter & $0.77(0.65-0.90)$ & $0.75(0.32-1.03)$ & $p=0.84$ \\
$\mathrm{NO}_{3}$ winter & $0.33(0.25-0.42)$ & $0.24(0.01-0.47)$ & $p=0.39$ \\
$\mathrm{NH}_{4}$ summer & $0.012(0.005-0.025)$ & $0.009(0.007-0.012)$ & $p=0.58$ \\
$\mathrm{NH}_{4}$ winter & $0.056(0.008-0.104)$ & $0.145(0.013-0.251)$ & $p=0.18$ \\
\hline
\end{tabular}

The seasonality of nutrient concentrations dependency on clear or turbid conditions and/or the abundance of macrophytes is illustrated by the ratio between summer and winter concentrations of TP, 
DIP, TN and CHL relative to Cov (Figure 5). In years with low Cov $(<10 \%)$, TP was 1.4-3.0 times (mean TPs_W $=2.30$ ) higher during summer than during the following winter, but in years with high Cov $(>20 \%)$ TP was in most years highest during winter (mean TPs_w $=0.75)$. The same pattern emerged for DIP (mean DIPs_w = 1.61 at low Cov and 0.49 at high Cov), TN (mean TNs_w $=1.02$ at low Cov and 0.36 at high Cov) and CHL (mean CHLs_w $=3.47$ at low Cov and 1.46 at high Cov). All three nutrient ratios and CHL differed significantly between high and low Cov (Table 3).
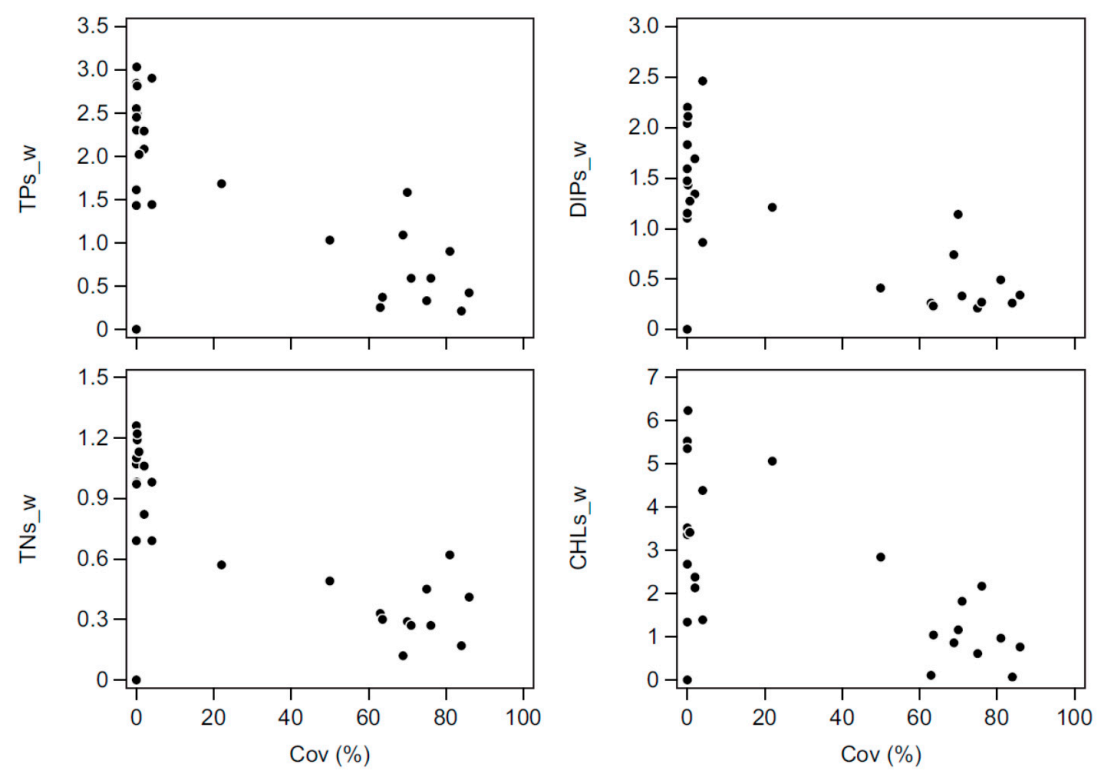

Figure 5. TPs_w, DIPs_w, TNs_w and CHLs_w relative to Cov from 1986 to 2015. No winter data available for 1992/1993 and 2002/2003.

A comparison of the various chemical variables following the first and second biomanipulation demonstrated no significant differences in nutrient concentrations under clear water conditions with Cov $>20 \%$ (Table 5). The only significant difference was found for summer TN, which was significantly lower after the second biomanipulation.

Table 5. Mean CHL and nutrient concentrations in years with Cov $>20 \%$ after the first (1989-1991, 1994-1995, $n=5$ ) and the second biomanipulation (2009-2015, $n=7)$. $t$-Test results for differences between the first and second biomanipulation (significant differences are marked with bold). According to the Bonferroni correction for multiple comparisons, the results were considered significant for $p<0.0056$, representing an overall alpha level of $<0.05$. No summer mean concentrations of DIN are given as $\mathrm{NO}_{3}$ and $\mathrm{NH}_{4}$ concentrations were often below the detection limits.

\begin{tabular}{cccc}
\hline Variable & $\begin{array}{c}\text { First Biomanipulation } \\
\text { Mean (Min-Max) }\end{array}$ & $\begin{array}{c}\text { Second Biomanipulation } \\
\text { Mean (Min-Max) }\end{array}$ & $\begin{array}{c}\text { Difference } \\
\text { First-Second }\end{array}$ \\
\hline CHL summer & $17.3(9.3-28.2)$ & $18.8(9.7-34.9)$ & $p=0.76$ \\
CHL winter & $60.4(5.0-265.5)$ & $14.3(3.8-29.3)$ & $p=0.42$ \\
TP summer & $0.085(0.050-0.168)$ & $0.054(0.034-0.093)$ & $p=0.16$ \\
TP winter & $0.130(0.039-0.242)$ & $0.069(0.049-0.104)$ & $p=0.12$ \\
DIP summer & $0.049(0.014-0.136)$ & $0.027(0.015-0.045)$ & $p=0.39$ \\
DIP winter & $0.067(0.023-0.136)$ & $0.054(0.032-0.086)$ & $p=0.50$ \\
TN summer & $0.57(0.47-0.66)$ & $0.27(0.14-0.44)$ & $p<\mathbf{0 . 0 0 1}$ \\
TN winter & $1.35(0.87-2.15)$ & $0.92(0.70-1.20)$ & $p=0.07$ \\
DIN winter & $0.74(0.60-0.90)$ & $0.54(0.39-0.68)$ & $p=0.0084$ \\
\hline
\end{tabular}

A box-plot representing the monthly average for the whole monitoring period (1986-2015) with either low or high Cov illustrates the seasonal differences in CHL and nutrients between turbid and 
clear periods (Figure 6). The results of a test of the differences between low and high Cov during the different months are shown in Table 6. At low Cov, maximum CHL generally occurred in August, and when Cov was high it usually peaked in March. CHL was significantly lower at high Cov than at low Cov from April to October. TP concentrations were markedly higher during summer, peaking in July-August, but only when Cov was low. From April to July and in September, TP was significantly lower at high Cov than at low Cov. Maximum TN tended to appear during summer when Cov was low and in winter when Cov was high. TN was significantly lower at high Cov than at low Cov from April to September. DIN was low during the whole summer season, from April to September at all Cov levels.
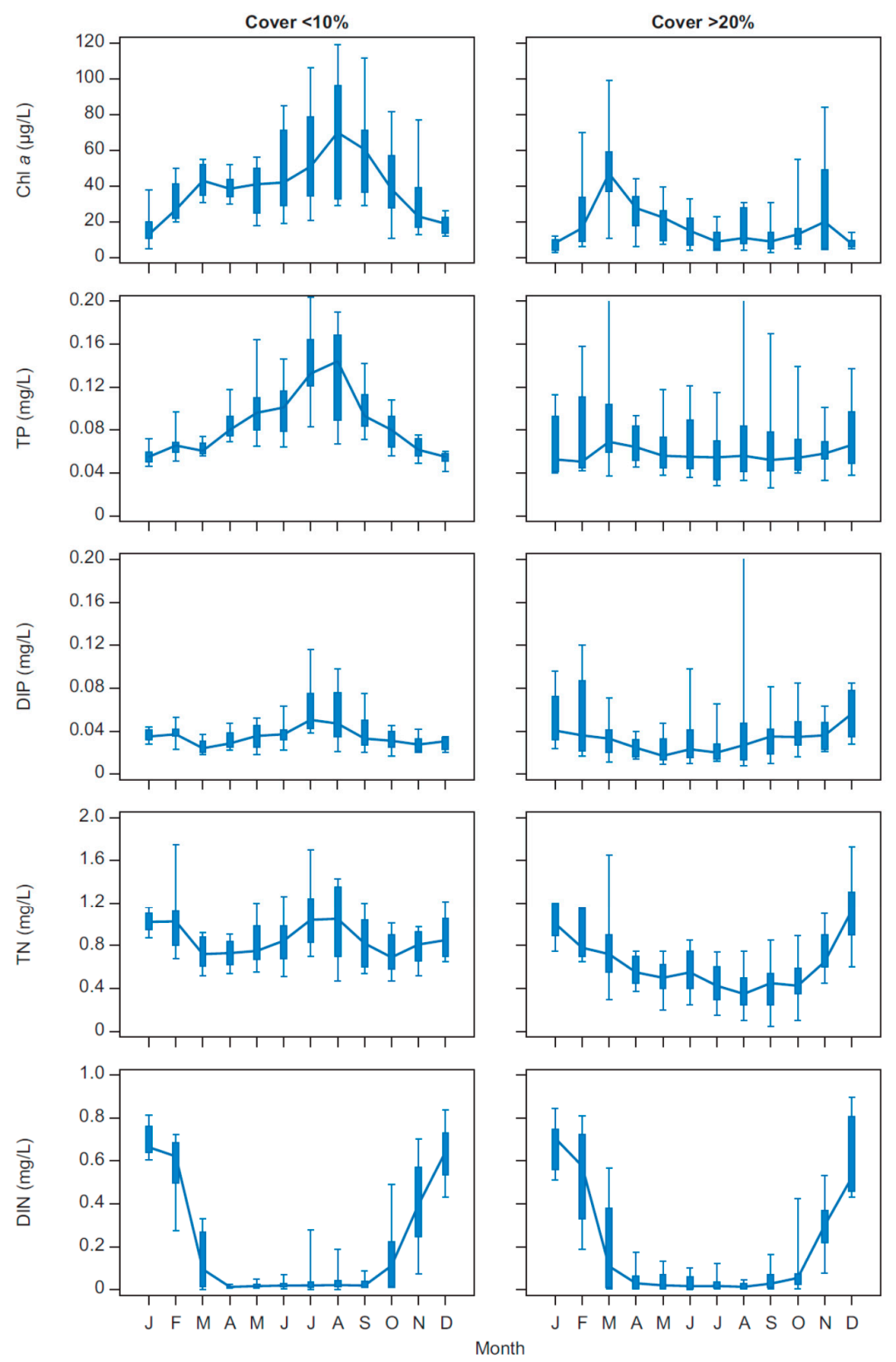

Figure 6. Box-plots showing monthly (January-December) seasonal CHL and nutrient concentrations during years with high $\operatorname{Cov}(\operatorname{Cov}>20 \%, 1989-1991,1994-1995$ and 2009-2015) and low $\operatorname{Cov}(\operatorname{Cov}<10 \%$, $1986-1988,1993$ and 1997-2008). The box-plots show 10\%, 25\%, 75\% and 90\% fractiles. Median values are connected by a solid line. 
Table 6. $t$-Test for monthly significant differences between low and high Cov for the variables and years shown in Figure 6: $-(p<0.05),--(p<0.01)$ and --- $(p<0.001)$ when the variable is lowest at high Cov and: $+(p<0.05)$ and $++(p<0.01)$ when the variable is highest at high Cov.

\begin{tabular}{ccccccccccccc}
\hline Variable, Month & Jan. & Feb. & Mar. & Apr. & May & Jun. & Jul. & Aug. & Sep. & Oct. & Nov. & Dec. \\
\hline CHL & & & & --- & -- & -- & -- & -- & -- & -- & & - \\
TP & & & & - & -- & - & -- & & -- & & & \\
DIP & & & & -- & -- & -- & -- & --- & -- & & & ++ \\
TN & & & & + & & & & - & & & & \\
DIN & & & & & & & & & & & & \\
\hline
\end{tabular}

\subsection{Submerged Macrophytes}

Cov fluctuated widely during the investigation period, from $<0.1 \%$ (no or very few macrophytes) to more than $80 \%$ (Figure 3). During the year of clear water after biomanipulation, Cov was relatively low, but maximum Cov occurred already 2-3 years after each biomanipulation. After the first biomanipulation, the macrophyte community collapsed in 1992-1993 and Cov decreased to $<20 \%$. After this, the macrophytes returned and reached high Cov again before they disappeared from 1997 and onwards until the second biomanipulation. After the second biomanipulation, Cov has remained high (64\%-75\% from 2010 to 2015).

The macrophyte community was dominated by Elodea canadensis throughout the periods with high Cov (Table 7). In some years, particularly after the first biomanipulation, Potamogeton crispus had a considerable cover, and in other years also the filamentous algae Lemna trisulca, P. pusillus and P. obtusifolius were richly represented. The macrophyte community exhibited higher richness (up to 10 taxa) after the second than after the first biomanipulation (up to four taxa).

The seasonality of the submerged macrophytes during the past 10 years shows a development from low to high Cov and PVI during a calendar year (Figure 7). In years with high density of macrophytes, they did not disappear during winter, but Cov, and in particular PVI, decreased to markedly lower levels (in most years from $>30 \%$ to $<10 \%$ ).

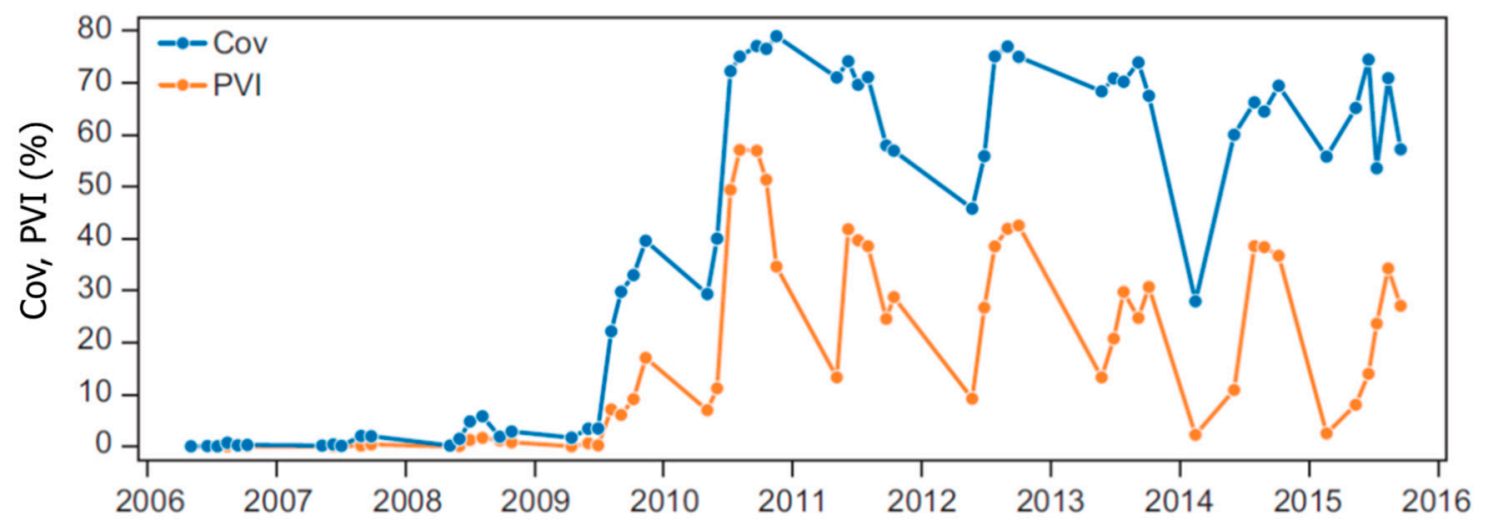

Figure 7. Seasonal Cov and PVI in Lake Væng during the past 10 years. 
Table 7. Submerged macrophytes, filamentous algae and indication of the mean summer cover of each taxon from 1986 to 2015.

\begin{tabular}{|c|c|c|c|c|c|c|c|c|c|c|c|c|c|c|c|c|c|c|c|c|c|c|c|c|c|c|c|c|c|c|}
\hline Species/Taxa & 86 & 87 & 88 & 89 & 90 & 91 & 92 & 93 & 94 & 95 & 96 & 97 & 98 & 99 & 00 & 01 & 02 & 03 & 04 & 05 & 06 & 07 & 08 & 09 & 10 & 11 & 12 & 13 & 14 & 15 \\
\hline Elodea canadensis & & - & - & $\mathbf{\square}$ & 口 & 口 & $\mathbf{\square}$ & $=$ & $\mathbf{\square}$ & 口 & 口 & - & - & & & & & - & - & - & - & - & $=$ & - & घ & [ & च & घ & च & 口 \\
\hline Filamentous algae & & & & & & & & & $=$ & - & & & & & & & & - & & & - & & - & $=$ & - & $\boldsymbol{\square}$ & $=$ & $=$ & - & $=$ \\
\hline Lemna trisulca & & & & & & & & & & & & & & & - & & & & & & & & & - & - & - & - & $=$ & $=$ & $=$ \\
\hline Nitella flexilis & & & & & & - & - & & & & & & - & & & & & & & & & & & & & & & - & - & - \\
\hline Potamogeton berctoldii & & & & & & & & & & & & & & & & & & & & & & & & - & & & & - & $=$ & $=$ \\
\hline P. crispus & - & - & $=$ & 口 & $=$ & - & - & - & $=$ & - & & & & & & - & & - & - & & - & - & - & & & - & & - & & - \\
\hline P. friesii & & & & & & & & & & & - & & & & & & & & & & & & - & & & & - & - & & \\
\hline P. obtusifolius & & & & & & & & & & & & & & & & & & & & & & & & & - & & & - & - & $=$ \\
\hline P. pectinatus & & & & & & & & & & - & & & & & & & & & & & & & & & - & & - & - & & - \\
\hline P. pusillus & & & & & & & & & & & & & & & & & & & & & & & & & - & & & - & $=$ & $=$ \\
\hline
\end{tabular}




\section{Discussion}

We would like to emphasise three main findings from our long-term study of Lake Væng: (1) biomanipulation by fish removal can greatly improve lake water quality for a number of years and repeated fish removal can help maintain the positive effects; (2) the effects of the fish removal cascade all the way down to the level of nutrients, altering the nitrogen and phosphorus cycling markedly on both the yearly and seasonal scale; and (3) less fishing effort seems needed at the second biomanipulation to achieve similar effects as during the first manipulation.

The effects of both biomanipulation attempts in Lake Væng were comparable with those obtained in other shallow Danish lakes [10], and in many other parts of the world as well [9,11,29]. We are not able to ascertain whether the fish biomass was lower before the second than before the first biomanipulation in Lake Væng, but the chemical and biological effects of the second biomanipulation appear to be just as strong as after the first biomanipulation, even though $30 \%$ less fish was removed. This indicates that a follow-up fish removal requires less effort, in our case probably due to the presence of a relatively large population of small perch after the first manipulation. These small perch have the potential to reach an older, larger and piscivorous stage after fish removal and thereby contribute to controlling the roach population [6]. Perch mean weight increased after both biomanipulations, reflecting the potential of perch to reach the piscivorous stage when mass removal of planktivorous and benthivorous fish produces a dietary change in the remaining species towards increased utilisation of benthic resources [30].

The effects obtained from the first and second biomanipulation were remarkably similar: within 1-2 years after the fish removal, the lake had changed from a turbid to clear water state with a strongly reduced phytoplankton biomass, within 2-3 years the submerged macrophyte community (dominated by Elodea after both biomanipulations) had developed from almost absence to almost complete cover all over the lake from bottom to surface and, finally, the shifts between turbid and clear water changed the internal cycling of nutrients markedly and in the same manner. After the second biomanipulation, lower nitrogen concentrations and a more diverse macrophyte community have been observed, but overall the effects of the two biomanipulations have been very similar and they suggest a strong top-down impact of fish followed by similar cascading effects. Although nutrients and phytoplankton are not independent variables, many of these effects most likely reflect the reduced phytoplankton biomass created through by less nutrients and higher zooplankton grazing [6] and improved light conditions, enabling a shift from mainly pelagic to mainly benthic primary producers. The major decline in CHL after biomanipulation has previously been shown to produce relatively minor effects on gross production and respiration but a higher seasonal amplitude in net production [6], reflecting the shift in dominant primary producers and higher variability in the biomass of macrophytes. Not many case studies on repeated fish removals are available, but in Dutch Lake Zwemlust a second fish removal was observed to create similar effects as the first removal [31]. The absence of long-term effects was ascribed to the high nutrient loading, which only allows submerged macrophytes to dominate in the "window of opportunity" occurring in the first years after the fish removal.

Both biomanipulations had pronounced effects on the nutrient concentrations in Lake Væng, and $\mathrm{TP}$ and TN were reduced to about $50 \%$ of pre-biomanipulation levels with increasing water clarity. As no changes in external loading have occurred, the lower concentrations must be produced by changes in the internal nutrient dynamics. Particularly, the internal summer release of phosphorus, which is often seen in shallow eutrophic lakes [32-34], most likely decreased notably, which suggests a radical change in the way that the sediment acts as a sink or source of phosphorus depending on the biological structure. Similar effects have been observed in other biomanipulated lakes and in comparisons of inside and outside submerged macrophyte stands [10,35]. This may in part be attributed to improved light conditions at the sediment surface. This leads to higher benthic primary production [36,37], facilitating the uptake of phosphorus from the lake water and a subsequent reduction of the sediment phosphorus release due to the improved redox conditions. More details on the role of benthic algae in the phosphorus exchange between sediment and water are available in [38]. 
In a Dutch shallow lake ecosystem [39], phosphorus concentrations fluctuated strongly relative to variations in the growth of aquatic plants despite the fact that external phosphorus loading was stable. Years with low Cov had higher P concentrations than years with high Cov, the patterns thus being identical with those recorded in Lake Væng. In addition, lower sedimentation of phytoplankton may increase redox conditions in the sediment and reduced fish-induced resuspension may contribute to lower internal P loading. For nitrogen, decreased density of cyprinids (mainly roach and bream) was observed to lead to decreased $\mathrm{N}$ concentrations and increased $\mathrm{N}$ retention in four Danish lakes [40]. In Lake Væng, summer N-ret $\%$ increased from $22 \%-39 \%$ before to $60 \%-72 \%$ after the first biomanipulation, probably due to a decrease in organic $\mathrm{N}$ in the lake, reduced resuspension by fish and higher denitrification in the sediment [40].

The importance of biological structure for the internal cycling of nutrients is also seen by the shifts in the seasonal concentrations of phosphorus, reflecting the high fluctuations in the abundance of submerged macrophytes. A likely explanation for the peaks in high winter concentrations of TP and DIP in periods with high Cov could be phosphorus release from decomposing macrophytes and redox sensitive release of phosphorus accumulated in the sediment. A dense and senescent macrophyte biomass at the sediment surface can result in reduced redox conditions and a reduced P sorption capacity [41].

Highly dynamic and cyclical growth of submerged macrophytes and regime shifts between turbid and clear water conditions as those seen in Lake Væng have been recorded in several other lakes $[39,42,43]$. In Lake Væng, P retention has been high, particularly after the second biomanipulation as demonstrated by low $\mathrm{P}$ concentrations in the lake water. Consequently, a mobile pool of phosphorus has accumulated in the sediment, a pool that may eventually be released, particularly if the lake returns to turbid conditions. High macrophyte Cov may then in the long term increase the risk of a return to turbid conditions, a negative feedback that might be supported by the build-up of decaying plant material in the sediment [37]. It has been suggested that also the climate may contribute to the regime shifts through lowered macrophyte production, and in Lake Tåkern, Sweden, an eight-year cyclic periodicity of organic nitrogen has been observed to depend on the seasonal macrophyte production [44]. Nitrogen may also be important, particularly for creating favourable growth conditions for submerged macrophytes, and high $\mathrm{N}$ concentrations have negative impacts on macrophytes [45-47].

In Lake Væng, the seasonality in phytoplankton biomass changed markedly after the two biomanipulations, with a shift from maximum CHL concentrations during summer when the lake was turbid and without macrophytes to a maximum in winter when the lake was clear and rich in macrophytes. During summer in the presence of macrophytes, phytoplankton may be limited by grazing from zooplankton and other filtrators, by nutrients and the low light availability caused by the high macrophyte density. The significantly low DIN levels throughout summer under both clear and turbid conditions indicate that phytoplankton may be limited by nitrogen during the major part of their growing season, as also seen in other Danish shallow lakes and in other parts of the world [48,49]. During winter, increased nutrient availability, lower macrophyte abundance and less tall macrophytes may increase the phytoplankton biomass.

The numbers of grazing waterfowl, mute swan (Cygnus olor) and coot (Fulica atra) have fluctuated widely in Lake Væng from year to year concurrently with the abundance of submerged macrophytes [23]. Waterfowl may negatively impact the abundance of submerged macrophytes and thereby the stability of clear water conditions, but even though waterfowl were present in high numbers in some years the decline in macrophytes cannot likely be ascribed to waterfowl grazing. A study from UK concluded that the potential of waterfowl herbivory to shift a macrophyte-dominated state into a phytoplankton-dominated state is low due to the recovery of aquatic plants during the growing season when bird populations decline [50]. In winter 1991/1992 in Lake Væng, the number of coot and mute swan reached a maximum of, respectively, 800 and 300 individuals. During this winter, Cov decreased from $84 \%$ to $44 \%$ and PVI from $60 \%$ to $10 \%$. Total macrophyte consumption by the waterfowl during this winter was estimated to $440 \mathrm{~kg} \cdot \mathrm{DW} \cdot \mathrm{ha}^{-1}$ [23]. The P content of Elodea varies relatively widely, but assuming a mean content of $0.7 \%$ of the dry weight [51] this would correspond 
to a potential release (if all phosphorus in the plant tissue is released to the water) of $3 \mathrm{~kg} \cdot \mathrm{P} / \mathrm{ha}$ or $0.3 \mathrm{mg} \cdot \mathrm{L}^{-1}$ (with a mean depth of $1 \mathrm{~m}$ ) during the whole winter. Thus, as the hydraulic retention in Lake Væng is only a few weeks, the increase caused by decomposing or ingested macrophytes can probably only explain a minor part of the increase seen in lake water nutrient concentrations.

The future environmental state of Lake Væng is uncertain and a number of unknown factors behind, for example, the fluctuating macrophyte abundance observed make predictions difficult. Factors in favour of clear water conditions are: (1) the macrophyte community appears more stable after the second biomanipulation with a more constant high abundance and presence of more species than after the first biomanipulation; (2) Nitrogen concentrations are lower now than after the first biomanipulation, augmenting the chances of submerged macrophytes maintaining their high abundance and thus stabilising clear water conditions [45,52]. Other factors could, however, indicate a return to turbid conditions: (i) the first biomanipulation did not create permanently clear water conditions; and (ii) the high nutrient concentrations in the groundwater may counteract the maintenance of clear water conditions [24]. The mean concentration of total phosphorus in the groundwater just below the lake bed is $0.162 \mathrm{mg} \cdot \mathrm{L}^{-1}$ [24]. However, as TP concentrations vary considerably between the groundwater wells, it is difficult to establish a precise phosphorus loading of the lake. It has been estimated (GEUS, personal communication) that Lake Væng receives between 200 and $280 \mathrm{~kg}$ P yearly with the groundwater, corresponding to $1.3-1.8 \mathrm{~g} \cdot \mathrm{P} \cdot \mathrm{m}^{-2} \cdot \mathrm{year}^{-1}$ or a mean inlet TP concentration of $0.12 \mathrm{mg} \cdot \mathrm{L}^{-1}$. This is more than twice as high as the suggested maximum levels of $0.6-0.8 \mathrm{~g} \cdot \mathrm{P} \cdot \mathrm{m}^{-2} \cdot$ year $^{-1}$ [53] in order to ensure long-term success of biomanipulation in shallow lakes; (3) Paleolimnological investigations of the upper $0.5 \mathrm{~m}$ of the sediment involving calculation of diatom-inferred TP concentrations indicate that Lake Væng has been eutrophic for centuries, with TP concentrations fluctuating between 100 and $160 \mu \mathrm{g} \cdot \mathrm{L}^{-1}$ [54]; (4) The dominance of Elodea may not favour stable clear water conditions as this submerged macrophyte species is known to show rapid changes in abundance. In a Dutch biomanipulation experiment, Elodea abundance showed high variability, ranging between high to sudden low abundances [55]; (5) The present high retention of phosphorus entails accumulation of a phosphorus pool in the surface of the sediment, and this might be released should the lake return to turbid conditions. Consequently, at the present nutrient levels, clear water conditions in Lake Væng are difficult to maintain, and regular repetition of biomanipulation therefore seems required.

Acknowledgments: The project was supported by the EU project MARS (Managing Aquatic ecosystems and water Resources under multiple Stress) funded under the 7th EU Framework Programme and CLEAR (a Villum Kann Rasmussen Centre of Excellence project). Anne Mette Poulsen and Tinna Christensen are acknowledged for editorial and layout assistance.

Author Contributions: Martin Søndergaard wrote the paper with input from Erik Jeppesen. All authors contributed with data sampling and comments to the paper.

Conflicts of Interest: The authors declare no conflicts of interest.

\section{References}

1. Shapiro, J.; Wright, D.I. Lake restoration by biomanipulation: Round Lake, Minnesota, the first 2 years. Freshw. Biol. 1984, 14, 371-383.

2. Jeppesen, E.; Søndergaard, M.; Mortensen, E.; Kristensen, P.; Riemann, B.; Jensen, H.J.; Müller, J.P.; Sortkjær, O.; Jensen, J.P.; Christoffersen, K.; et al. Fish manipulation as a lake restoration tool in shallow, eutrophic temperate lakes 1: Cross-analysis of three Danish case-studies. Hydrobiologia 1990, 200/201, 205-218. [CrossRef]

3. Jeppesen, E.; Jensen, J.P.; Kristensen, P.; Søndergaard, M.; Mortensen, E.; Sortkjær, O.; Olrik, K. Fish manipulation as a lake restoration tool in shallow, eutrophic, temperate lakes 2: Threshold levels, long-term stability and conclusions. Hydrobiologia 1990, 200/201, 219-227. [CrossRef]

4. Moss, B.; Madgwick, J.; Phillips, G. A Guide to the Restoration of Nutrient-Enriched Shallow Lakes; Broads Authority: Norwich, UK, 1996. 
5. Perrow, M.R.; Meijer, M.L.; Dawidowicz, P.; Coops, H. Biomanipulation in shallow lakes: State of the art. Hydrobiologia 1997, 342, 355-365. [CrossRef]

6. Jeppesen, E.; Søndergaard, M.; Lauridsen, T.L.; Davidson, T.A.; Liu, Z.; Mazzeo, N.; Trochine, C.; Özkan, K.; Jensen, H.S.; Trolle, D.; et al. Biomanipulation as a restoration tool to combat eutrophication: Recent advances and future challenges. Adv. Ecol. Res. 2012, 47, 411-487.

7. Fulton, R.S.; Godwin, W.F.; Schaus, M.H. Water quality changes following nutrient loading reduction and biomanipulation in a large shallow subtropical lake, Lake Griffin, Florida, USA. Hydrobiologia 2015, 753, 243-263. [CrossRef]

8. Scheffer, M.; Portielje, R.; Zambrano, L. Fish facilitate wave resuspension of sediment. Limnol. Oceanogr. 2003, 48, 1920-1926. [CrossRef]

9. Hansson, L.-A.; Annadotter, H.; Bergman, E.; Hamrin, S.F.; Jeppesen, E.; Kairesalo, T.; Luokkanen, E.; Nilsson, P.-Å.; Søndergaard, M.; Strand, J. Biomanipulation as an application of food-chain theory: Constraints, synthesis, and recommendations for temperate lakes. Ecosystems 1998, 1, 558-574. [CrossRef]

10. Søndergaard, M.; Liboriussen, L.; Pedersen, A.R.; Jeppesen, E. Lake restoration by fish removal: Short- and long-term effects in 36 Danish lakes. Ecosystems 2008, 11, 1291-1305. [CrossRef]

11. Peretyatko, A.; Teissier, S.; de Backer, S.; Triest, L. Biomanipulation of hyper-eutrophic ponds: When it works and why it fails. Environ. Monit. Assess. 2012, 184, 1517-1531. [CrossRef] [PubMed]

12. Meijer, M.L.; de Boois, I.; Scheffer, M.; Portielje, R.; Hosper, H. Biomanipulation in shallow lakes in The Netherlands: An evaluation of 18 case studies. Hydrobiologia 1999, 409, 13-30. [CrossRef]

13. Gulati, R.D.; van Donk, E. Lakes in the Netherlands, their origin, eutrophication and restoration: State-of-the-art review. Hydrobiologia 2002, 478, 73-106. [CrossRef]

14. Søndergaard, M.; Jeppesen, E.; Lauridsen, T.L.; Skov, C.; van Nes, E.H.; Roijackers, R.; Lammens, E.; Portielje, R. Lake restoration: Successes, failures and long-term effects. J. Appl. Ecol. 2007, 44, 1095-1105. [CrossRef]

15. Benndorf, J.; Boing, W.; Koop, J.; Neubauer, I. Topdown control of phytoplankton: The role of time scale, lake depth and trophic state. Freshw. Biol. 2002, 47, 2282-2295. [CrossRef]

16. Mehner, T.; Benndorf, J.; Kasprzak, P.; Koschel, R. Biomanipulation of lake ecosystems: Successful applications and expanding complexity in the underlying science. Freshw. Biol. 2002, 47, 2453-2465. [CrossRef]

17. Jeppesen, E.; Jensen, J.P.; Søndergaard, M.; Lauridsen, T.; Landkildehus, F. Trophic structure, species richness and biodiversity in Danish lakes: Changes along a phosphorus gradient. Freshw. Biol. 2000, 45, 201-213. [CrossRef]

18. Jeppesen, E.; Sammalkorpi, I. Lakes. In Handbook of Ecological Restoration; Perrow, M.R., Davy, A.J., Eds.; Restoration in Practice; Cambridge University Press: Cambridge, UK, 2002; Volume 2, pp. 297-324.

19. Jeppesen, E.; Søndergaard, M.; Søndergaard, M.; Christoffersen, K. (Eds.) The Structuring Role of Submerged Macrophytes in Lakes; Ecological Studies 131; Springer: New York, NY, USA, 1998.

20. Gulati, R.D.; Pires, L.M.D.; van Donk, E. Lake restoration studies: Failures, bottlenecks and prospects of new ecotechnological measures. Limnologica 2008, 38, 233-247. [CrossRef]

21. Søndergaard, M.; Jeppesen, E.; Mortensen, E.; Dall, E.; Kristensen, P.; Sortkjær, O. Phytoplankton biomass reduction after planktivorous fish reduction in a shallow, eutrophic lake: A combined effect of reduced internal P-loading and increased zooplankton grazing. Hydrobiologia 1990, 200, 229-240. [CrossRef]

22. Lauridsen, T.; Jeppesen, E.; Andersen, F.Ø. Colonization of submerged macrophytes in shallow fish manipulated Lake Væng: Impact of sediment composition and waterfowl grazing. Aquat. Bot. 1993, 46, 1-15. [CrossRef]

23. Søndergaard, M.; Lauridsen, T.L.; Jeppesen, E.; Bruun, L. Macrophyte-waterfowl interactions: Tracking a variable resource and the impact of herbivory on plant growth. In The Structuring Role of Submerged Macrophytes in Lakes; Ecological Studies 131; Springer: New York, NY, USA, 1998; pp. 298-306.

24. Kidmose, J.; Nilsson, B.; Engesgaard, P.; Frandsen, M.; Karan, S.; Landkildehus, F.; Søndergaard, M.; Jeppesen, E. Focused groundwater discharge of phosphorus to a eutrophic seepage lake (Lake Væng, Denmark): Implications for lake ecological state and restoration. Hydrogeol. J. 2013, 21, 1787-1802. [CrossRef]

25. Mortensen, E.; Jensen, H.J.; Müller, J.P.; Timmermann, M. Fiskeundersøgelser i Søer: Overvågningsprogram; Undersøgelsesprogram, Fiskeredskaber og Metoder, Teknisk Anvisning No. 3; Danmarks Miljøundersøgelser: Silkeborg, Denmark, 1993. 
26. Jeppesen, E.; Jensen, J.P.; Søndergaard, M.; Fenger-Grøn, M.; Sandby, S.; Hald Møller, P.; Rasmussen, H.U. Does fish predation influence zooplankton community structure and grazing during winter in north-temperate lakes? Freshw. Biol. 2004, 49, 432-447. [CrossRef]

27. Søndergaard, M.; Jeppesen, E.; Jensen, J.P.; Amsinck, S.L. Water framework directive: Ecological classification of Danish lakes. J. Appl. Ecol. 2005, 42, 616-629. [CrossRef]

28. Søndergaard, M.; Larsen, S.E.; Johansson, L.S.; Lauridsen, T.L.; Jeppesen, E. Ecological classification of lakes: Uncertainty and the influence of year-to-year variability. Ecol. Indic. 2016, 61, 248-257. [CrossRef]

29. Drenner, R.; Hambright, K. Biomanipulation of fish assemblages as a lake restoration technique. Arch. Hydrobiol. 1999, 146, 129-165.

30. Persson, A.; Hansson, L.A. Diet shift in fish following competitive release. Can. J. Fish. Aquat. Sci. 1999, 56, 70-78. [CrossRef]

31. Van de Bund, W.J.; van Donk, E. Short-term and long-term effects of zooplanktivorous fish removal in a shallow lake: A synthesis of 15 years of data from Lake Zwemlust. Freshw. Biol. 2002, 12, 2380-2387. [CrossRef]

32. Kleeberg, A.; Kozerski, H.-P. Phosphorus release in Lake Großer Müggelsee and its implications for lake restoration. Hydrobiologia 1997, 242, 9-26. [CrossRef]

33. Graneli, W. Internal phosphorus loading in Lake Ringsjön. Hydrobiologia 1999, 404, 19-26. [CrossRef]

34. Søndergaard, M.; Bjerring, R.; Jeppesen, E. Persistent internal phosphorus loading during summer in shallow eutrophic lakes. Hydrobiologia 2013, 710, 95-107. [CrossRef]

35. Horppila, J.; Nurminen, L. Effects of submerged macrophytes on sediment resuspension and internal phosphorus loading in Lake Hiidenvesi (Southern Finland). Water Res. 2003, 37, 4468-4474. [CrossRef]

36. Vadeboncoeur, Y.; Jeppesen, E.; Vander Zanden, M.J.; Schierup, H.H.; Christoffersen, K.; Lodge, D. From Greenland to green lakes: Cultural eutrophication and the loss of benthic pathways in lakes. Limnol. Oceanogr. 2003, 48, 1408-1418. [CrossRef]

37. Liboriussen, L.; Jeppesen, E. Temporal dynamics in epipelic, pelagic and epiphytic algal production in a clear and a turbid shallow lake. Freshw. Biol. 2003, 48, 418-431. [CrossRef]

38. Zhang, X.; Liu, Z.; Ramesh, D.; Gulati, R.D.; Jeppesen, E. The effect of benthic algae on phosphorus exchange between sedimentand overlying water in shallow lakes: A microcosm study using 32P as a tracer. Hydrobiologia 2013, 710, 109-116. [CrossRef]

39. Rip, W.; Ouboter, M.R.L.; van Ness, E.H.; Beltman, B. Oscillation of a shallow lake ecosystem upon reduction in external phosphorus load. Arch. Hydrobiol. 2005, 164, 387-409. [CrossRef]

40. Jeppesen, E.; Jensen, J.P.; Søndergaard, M.; Lauridsen, T.; Møller, F.P.; Sandby, K. Changes in nitrogen retention in shallow eutrophic lakes following a decline in density of cyprinids. Arch. Hydrobiol. 1998, 142, 129-151.

41. Boros, G.; Søndergaard, M.; Takács, P.; Vári, Á.; Tátrai, I. Influence of submerged macrophytes, temperature, and nutrient loading on the development of redox potential around the sediment-water interface in lakes. Hydrobiologia 2011, 665, 117-127. [CrossRef]

42. Blindow, I.; Andersson, G.; Hargeby, A.; Johansson, S. Long-term pattern of alternative stable states in 2 shallow eutrophic lakes. Freshw. Biol. 1993, 30, 159-167. [CrossRef]

43. Kornijów, R.; Kowalewski, G.; Sugier, P.; Kaczorowska, A.; Gasiorowski, M.; Woszczyk, M. Towards a more precisely defined macrophyte-dominated regime: The recent history of a shallow lake in Eastern Poland. Hydrobiologia 2016, 772, 45-62. [CrossRef]

44. Hargeby, A.; Jonzén, N.; Blindow, I. Does a long-term oscillation in nitrogen concentration reflect climate impact on submerged vegetation and vulnerability to state shifts in a shallow lake? Oikos 2006, 115, 334-348. [CrossRef]

45. Gonzalez Sagrario, M.A.; Jeppesen, E.; Goma, J.; Søndergaard, M.; Jensen, J.P.; Lauridsen, T. Does high nitrogen loading prevent clear-water conditions in shallow lakes at moderately high phosphorus concentrations? Freshw. Biol. 2015, 50, 27-41. [CrossRef]

46. Barker, T.; Hatton, K.; O'Connor, M.; Connor, L.; Moss, B. Effects of nitrate load on submerged plant biomass and species richness: Results of a mesocosm experiment. Fundam. Appl. Limnol. 2008, 173, 89-100. [CrossRef]

47. Olsen, S.; Jeppesen, E.; Moss, B.; Özkan, K.; Beklioglu, M.; Feuchtmayr, H.; Sagrario, M.G.; Wei, L.; Larsen, S.E.; Lauridsen, T.L.; et al. Factors influencing nitrogen processing in lakes: An experimental approach. Freshwt. Biol. 2015, 60, 646-662. [CrossRef] 
48. Xu, H.; Paerl, H.W.; Qin, B.Q.; Zhu, G.W.; Gao, G. Nitrogen and phosphorus inputs control phytoplankton growth in eutrophic Lake Taihu, China. Limnol. Oceanogr. 2010, 55, 420-432. [CrossRef]

49. Kolzau, S.; Wiedner, C.; Rücker, J.; Köhler, J.; Köhler, A.; Dolman, A.M. Seasonal patterns of nitrogen and phosphorus limitation in four German lakes and the predictability of limitation status from ambient nutrient concentrations. PLoS ONE 2014, 9, e96065. [CrossRef] [PubMed]

50. Chaichana, R.; Leah, R.; Moss, B. Seasonal impact of waterfowl on communities of macrophytes in a shallow lake. Aquat. Bot. 2011, 95, 39-44. [CrossRef]

51. Garbey, C.; Murphy, K.J.; Thiébaut, G.; Muller, S. Variation in P-content in aquatic plant tissues offers an efficient tool for determining plant growth strategies along a resource gradient. Freshw. Biol. 2004, 49, 346-356. [CrossRef]

52. Moss, B.; Jeppesen, E.; Søndergaard, M.; Lauridsen, T.L.; Liu, Z. Nitrogen, macrophytes, shallow lakes and nutrient limitation: Resolution of a current controversy? Hydrobiologia 2013, 710, 3-21. [CrossRef]

53. Kasprzak, P.; Benndorf, J.; Mehner, T.; Koschel, R. Biomanipulation of lake ecosystems: An introduction. Freshw. Biol. 2002, 47, 2277-2281. [CrossRef]

54. Anderson, N.J.; Odgaard, B.V. Recent palaeolimnology of three shallow Danish lakes. Hydrobiologia 1994, 275, 411-422. [CrossRef]

55. Pot, R.; Ter Heerdt, G.N.J. Succession dynamics of aquatic lake vegetation after restoration measures: Increased stability after 6 years of development. Hydrobiologia 2014, 737, 333-345. [CrossRef]

(C) 2017 by the authors; licensee MDPI, Basel, Switzerland. This article is an open access article distributed under the terms and conditions of the Creative Commons Attribution (CC-BY) license (http://creativecommons.org/licenses/by/4.0/). 